Article

\title{
The Effect of Quality Attributes on Visiting Consumers' Patronage Intentions of Green Restaurants
}

\author{
Yi Shan Yu ${ }^{1}$, Min Luo ${ }^{2, *}$ and Dong Hong Zhu ${ }^{3}$ \\ 1 School of Economics, Huazhong University of Science \& Technology, Wuhan 430074, China; \\ yushanshanyi@126.com \\ 2 School of Intellectual Property, Nanjing University of Science \& Technology, Nanjing 210094, China \\ 3 School of Management, Huazhong University of Science \& Technology, Wuhan 430074, China; \\ zhudonghong1982@126.com \\ * Correspondence: luomin0604@126.com; Tel.: +86-025-84303345
}

Received: 6 March 2018; Accepted: 11 April 2018; Published: 15 April 2018

\begin{abstract}
Green consumption has become increasingly popular. More and more green restaurants are entering the market. The development of mobile Internet and the application of location-based services leads customers to easily visit several restaurants before making choice. Retaining a visiting customer is very important to green restaurants in the mobile Internet era. This paper develops a theoretical model to explore how the food-related, service-related and ambiance-related attributes of green restaurants influence the confirmation of expectations regarding restaurant quality and subsequent patronage intentions of visiting consumers in the context of location-based recommendations. The theoretical model is tested using the partial least squares method. The results show that the confirmation of expectations of food quality is determined by food presentation, variety and freshness; the confirmation of expectations of service quality is determined by employees and service; and the confirmation of expectations of ambiance quality is determined by cleanliness, design and décor, in terms of a positive effect on the patronage intention of visiting consumers of green restaurants making use of location-based recommendations. Finally, theoretical and practical implications are discussed.
\end{abstract}

Keywords: green restaurant; quality; patronage intention; location-based recommendations

\section{Introduction}

With the spread of the consciousness of environmental sustainability, green consumption has become increasingly popular. More and more green restaurants are entering the market. The survival and development of green restaurants relies on the patronage of consumers.

The development of mobile Internet and the application of location-based services enable restaurants to entice customers through initiative location-based recommendations [1-3]. Location-based recommendations may entice customers to visit the recommended restaurant. Despite these recommendations, a customers' decision to consume is determined by whether the restaurant satisfies their expectations after their observations. Meanwhile, using their mobile phone customers can search restaurants around them anytime and anywhere. As visiting several interesting restaurants in different places before making a choice becomes very easy for customers with mobile phones, retaining visiting customers is very important to green restaurants in the new mobile Internet era.

Restaurant quality plays an important role in restaurant consumption decision-making [4]. Previous studies have demonstrated that food, service, and ambiance quality are the key elements according to which customers make restaurant quality evaluations [4-6]. The type of restaurant 
moderates the relationship between a restaurant's quality attributes and a customer's behavioral intentions [6]. Though several studies have examined the antecedents of green restaurant patronage intentions, knowledge of how the food, service and ambiance quality attributes of green restaurants influence visiting customers' patronage intentions in the context of location-based recommendations is scarce. Hence, the present study aims to develop a theoretical model to explore how these quality attributes of green restaurants influence the confirmation of visiting customers' expectations of restaurant quality and subsequent patronage intentions in the context of location-based recommendations. Our findings can help improve the business performance of green restaurants in the new mobile Internet era.

\section{Literature Review}

\subsection{Green Restaurants}

Previous studies have investigated some antecedents of purchasing behavior toward green restaurants regarding consumers' knowledge and beliefs in relation to green consumption, individual characteristics and the green attributes of green restaurants (Table 1).

Table 1. Summary of findings related to green restaurants in the recent literature.

\begin{tabular}{cl}
\hline Author & \multicolumn{1}{c}{ Findings } \\
\hline $\begin{array}{c}\text { Hu et al., } \\
2010 \text { [7] }\end{array}$ & $\begin{array}{l}\text { Knowledge of a restaurant's sustainable practices and environmental concerns is an } \\
\text { important antecedent of consumers' green restaurant patronage intentions. }\end{array}$ \\
\hline $\begin{array}{c}\text { Liu \& Yu, } \\
2012 \text { [8] }\end{array}$ & Consumers' beliefs affect attitudes and patronage intentions towards green restaurants. \\
\hline $\begin{array}{c}\text { Chou et al., } \\
\text { 2012 [10] }\end{array}$ & $\begin{array}{l}\text { Perceived innovation characteristics affect the intention to adopt green practices in } \\
\text { restaurants through attitude, and perceived behavioral control affects the intention to adopt. }\end{array}$ \\
\hline $\begin{array}{c}\text { DiPietro et al., } \\
2013 \text { [11] }\end{array}$ & $\begin{array}{l}\text { Female customers and people with higher education are more conscious regarding green } \\
\text { practices. In addition, customers who utilize green practices at home intend to visit green } \\
\text { restaurants more often. }\end{array}$ \\
\hline Teng et al., & $\begin{array}{l}\text { Consumer values and attitudes affect their intentions to visit green restaurants. Attitude is } \\
\text { affected by consumer values and environmental concerns. }\end{array}$ \\
\hline $\begin{array}{c}\text { Chen et al., } \\
2015 \text { [13] }\end{array}$ & $\begin{array}{l}\text { The service quality of green restaurants includes seven dimensions: tangible, empathetic, } \\
\text { reliable, responsive, assuring, environmentally-oriented, and food quality. }\end{array}$ \\
\hline $\begin{array}{c}\text { Kwok et al., } \\
2016 \text { [14] }\end{array}$ & $\begin{array}{l}\text { Environment-focused attributes are the most important green attributes of restaurant. } \\
\text { Consumers who value food-focused and administration-focused attributes and younger } \\
\text { consumers are more likely to pay more, wait longer, and/or go farther to dine at a green }\end{array}$ \\
$\begin{array}{l}\text { Families with children value food-focused attributes more than those without children. } \\
\text { Jang, 2017 [12] }\end{array}$ & $\begin{array}{l}\text { Age, previous experience, involvement and self-perception affect consumers' willingness to } \\
\text { pay more for green practices in restaurants. }\end{array}$ \\
\hline Namkung
\end{tabular}

Regarding customers' knowledge and beliefs in relation to green consumption, Hu et al. examined the effect of knowledge of a restaurant's sustainable practices and environmental concerns on the patronage intention of customers towards green restaurants [7]. Liu and Yu examined the effect of customers' beliefs on attitudes towards green restaurants and patronage intentions in Taiwan [8]. Teng et al. examined the effect of consumers' values, attitudes and environmental concerns on intentions to visit green restaurants in Taiwan [9]. Regarding the aspect of individual characteristics, Chou et al. investigate the effect of perceived innovation, attitude and perceived behavioral control on the adoption of green practices in restaurants in Taiwan [10]. DiPietro et al. examined the effect of gender, education, and green practices experience on green practices consciousness in an upscale, green-certified restaurant [11]. Namkung and Jang investigated the effect of age, previous experience, involvement and self-perception on customers' willingness to pay more for green practices 
in restaurants [12]. Regarding the green attributes of green restaurants, Chen et al. developed a green restaurant service quality scale [13]. From the perspective of environment-focused, food-focused, and administration-focused attributes, Kwok et al. investigated the most important green attributes of restaurants and the effect of consumers' attitudes toward various green attributes on their behavioral intentions [14]. Table 1 summarizes the key findings of the recent literature on green restaurants.

In general, though the food, service, and ambiance quality of green restaurants affect the consumption behavior of consumers [13,14], little effort has been made to investigate the effect of green restaurant quality attributes on the confirmation of visiting customers' expectations of quality and subsequent patronage intentions. The present study aims to solve this question.

\subsection{Quality Attributes of Restaurants}

Quality attributes are important antecedents of customer behavioral intentions in the service industry [15-17]. Previous studies suggest that the quality attributes of restaurants mainly consist of food quality, service quality and ambiance quality $[4-6,16,18]$. For example, Ha and Jang argued that restaurant attributes are associated with food, service and the environment [5]. Bujisic et al. suggested that food, service and ambiance are three common restaurant attributes [6].

Given the importance of the quality attributes of restaurants, the specific attributes of food quality, service quality and ambiance quality have been investigated in previous studies [16,19]. Liu and Jang gathered and categorized the specific attributes mentioned in the relevant literature [16]. A total of 21 attributes were identified from the food, service and ambiance categories of attributes (Table 2).

Table 2. Restaurant quality attributes.

\begin{tabular}{clll}
\hline Source & Food Attributes & \multicolumn{1}{c}{ Service Attributes } & \multicolumn{1}{c}{ Ambiance Attributes } \\
\hline & Food taste & Serve food as ordered & Cleanliness of environment * \\
& Food safety & Accurate guest check & Employee appearance * \\
Liu \& Jang & Food freshness * & Dependable and consistent service & Odor \\
[16] & Food temperature & Prompt service * & Room temperature \\
& Food variety * & Friendly and helpful employees * & Lighting \\
& Food presentation * & Attentive employees & Interior design and décor * \\
& Healthy options & Employees have knowledge of menu & Music \\
\hline
\end{tabular}

In the context of location-based recommendations, visiting consumers' quality perceptions come from on-the-spot observations. Hence, certain food quality attributes (taste, safety and temperature) and service quality attributes (food served as ordered, accurate guest check, dependable and consistent service and employees have knowledge of the menu), which are related to practical consumption experience, were not employed in the present study. As healthy options is similar to food variety in the context of green restaurants, it was not involved in the present study. As music is not an important attribute [16], it was also not involved in the present study. Finally, food freshness, variety, and presentation (food quality), friendly and helpful employees and prompt service (service quality), and environmental cleanliness, employee appearance, lighting, and interior design and décor (ambiance quality) were employed as the special attributes of food quality, service quality and ambiance quality in the present study.

\section{Theoretical Model and Hypotheses}

\subsection{Theoretical Model}

Expectation confirmation theory is widely applied in the field of consumer behavior to study consumer continuance intentions [20-22]. Oliver argues that customers have pre-purchase expectations of a product or service they intend to purchase, which create an initial reference point according to which one makes a comparative judgment [23]. Based on Oliver's idea in [23], expectation confirmation 
theory suggests that the continuance intention of users is driven by their satisfaction with use and cognitive beliefs, which are determined by the confirmation of expectations from usage [24]. Moreover, the direct influence of the confirmation of expectations on continuance intentions has been verified $[25,26]$.

In the context of location-based recommendations, the restaurant information involved in a recommendation may affect the quality expectations of consumers. When they visit a restaurant, the actual conditions found during on-the-spot observation can help them determine the extent to which their expectations are confirmed, after which they form their consumption decision. The decision process of visiting consumers is similar to expectation confirmation theory. Hence, though expectation confirmation theory was developed to understand post-purchase continuance intentions [24], the present study draws on expectation confirmation theory to investigate visiting consumers' decisions to patronize a restaurant in the context of location-based recommendations. As the confirmation of expectations has a direct impact on continuance intentions $[25,26]$ and the restaurant patronage intentions of customers are affected by the quality of food, service, and ambiance $[6,27,28]$, the present study proposes that the confirmation of expectations regarding food quality, service quality and ambiance quality as a result of perceptions of food, service and ambiance quality attributes influences the patronage intention of visiting consumers towards green restaurants. Figure 1 shows the research model.

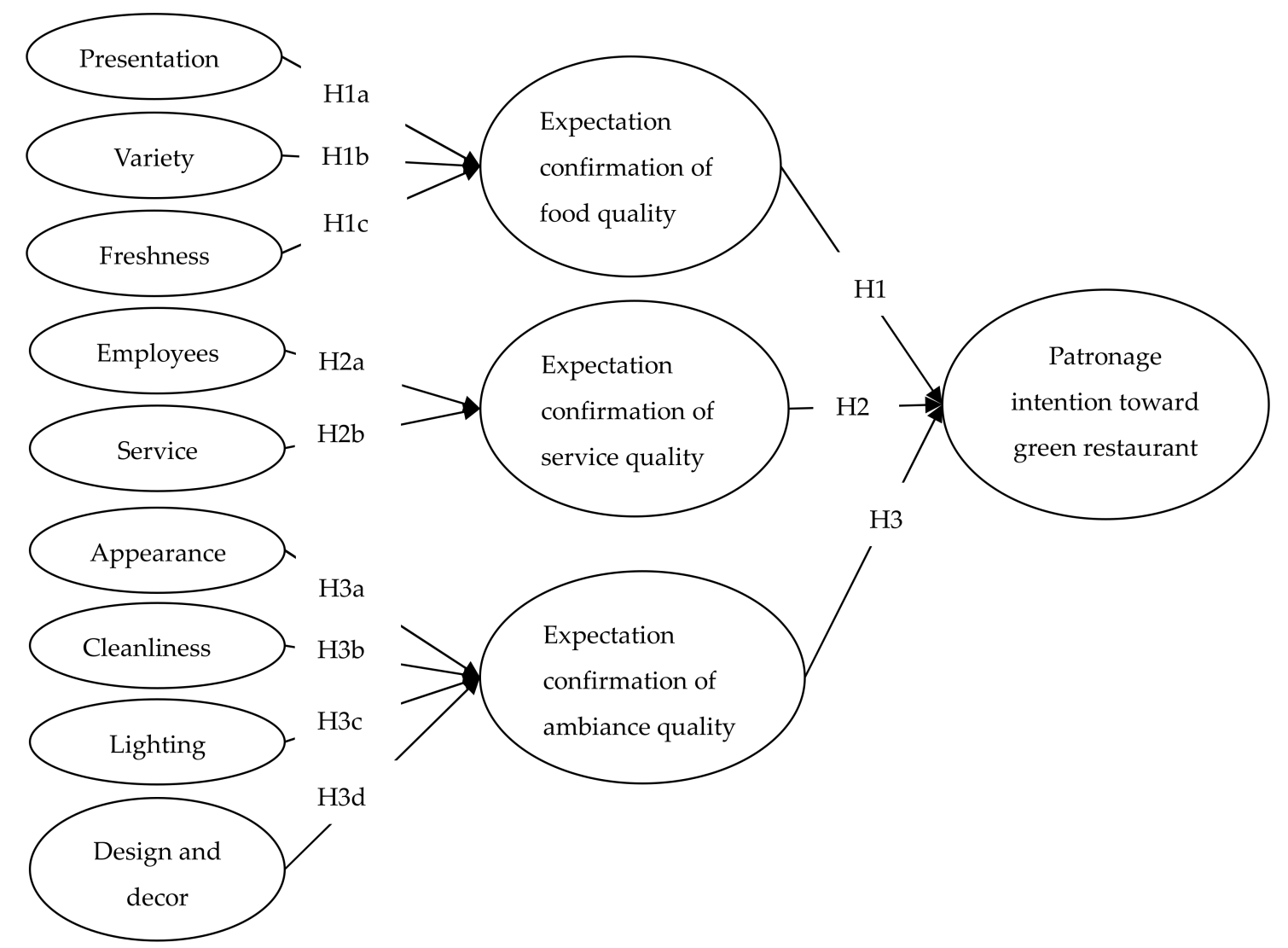

Figure 1. The research model.

\subsection{Hypotheses}

In the context of location-based recommendations, the recommendation information may affect customers' quality expectations regarding the green restaurant involved. When they visit the green restaurant, the actual conditions of the restaurant, learned from on-the-spot observations, can help them determine the extent to which their quality expectations are confirmed, before they form their 
consumption decision. Previous studies demonstrate that the confirmation of expectations has a direct impact on consumers' continuance intentions $[25,26]$. Hence, the present study proposes that the extent to which visiting consumers' quality expectations of a recommended green restaurant are confirmed affects their patronage intention. In addition, the restaurant patronage intention of customers is affected by the quality of food, service and ambiance. For example, Pan and Zinkhan found a strong positive relationship between perceived quality of food and customer's patronage intentions [29]. The direct effect of perceived quality of service on patronage intention has been widely demonstrated [29-31]. Rajic and Dado proved that a retail store's ambiance has a positive effect on customer's behavioral intentions [31]. Thus, the present study proposes that the confirmation of a visiting customers expectations regarding the quality of food, service and ambiance will affect their patronage intention towards a green restaurant involved in a location-based recommendation. The following hypotheses are proposed.

H1. Confirmation of expectations regarding food quality positively affects the patronage intention of visiting consumers toward green restaurants.

H2. Confirmation of expectations regarding service quality positively affects the patronage intention of visiting consumers toward green restaurants.

H3. Confirmation of expectations regarding ambiance quality positively affects the patronage intention of visiting consumers toward green restaurants.

Previous studies have suggested that customers rely on specific attributes of restaurants to evaluate the quality of the food, service and ambiance [16,19]. In the context of location-based recommendations, visiting consumers need to judge the extent to which their expectations of the food, service and ambiance quality are confirmed by their on-the-spot observations. Hence, the present study proposes that the food-, service- and ambiance-related specific attributes of green restaurants affect the confirmation of visiting consumers' expectations regarding food, service and ambiance quality.

In terms of the food, Namkung and Jang found that consumer perception of the quality of food presentation, food variety and food freshness are important attributes that determined the behavioral intentions of customers [15]. Liu and Jang argued that food presentation, food variety and food freshness are important food-related attributes [16]. Hence, the present study employs food presentation, food variety and food freshness as important food-related attributes of a green restaurant. In the context of location-based recommendations, visiting consumers can evaluate the presentation, variety and freshness of food by on-the-spot observations, which can help them judge the extent to which their expectations regarding food quality are confirmed. Thus, we predict that food presentation, food variety and food freshness will significantly affect the confirmation of visiting customers' expectations regarding food quality in green restaurants. The following hypotheses are proposed.

H1a. Food presentation positively affects the confirmation of visiting customers' expectations regarding food quality.

H1b. Food variety positively affects the confirmation of visiting customers' expectations regarding food quality.

Hc. Food freshness positively affects the confirmation of visiting customers' expectations regarding food quality.

In terms of service, Liu and Jang have argued that friendly and helpful employees and prompt service are important attributes [16]. Hence, the present study employs employees and service as important service-related attributes of green restaurants. In the context of location-based recommendations, visiting consumers can evaluate the attitude of employees and their service by on-the-spot observations, which can help them judge the extent to which their expectations regarding service quality are confirmed. Thus, we predict that employees and service will significantly affect the confirmation of visiting customers' expectations of service quality in green restaurants. The following hypotheses are proposed. 
H2a. Employees positively affect the confirmation of visiting customers' expectations regarding service quality.

H2b. Service positively affects the confirmation of visiting customers' expectations regarding service quality.

In terms of ambiance, Liu and Jang argued that the cleanliness of the environment, employee appearance, lighting, and interior design and décor are important attributes [16]. Hence, the present study employs environmental cleanliness, employee appearance, lighting, and interior design and décor as important ambiance-related attributes of green restaurants. In the context of location-based recommendations, visiting consumers can evaluate the environmental cleanliness, employee appearance, lighting, and interior design and décor of green restaurants by on-the-spot observations, which can help them judge the extent to which their expectations regarding ambiance quality are confirmed. Thus, we predict that environmental cleanliness, employee appearance, lighting, and interior design and décor will significantly affect the confirmation of visiting customers' expectations regarding ambiance quality in green restaurants. The following hypotheses are proposed.

H3a. Employee appearance positively affects the confirmation of visiting customers' expectations regarding ambiance quality.

H3b. Cleanliness positively affects the confirmation of visiting customers' expectations regarding ambiance quality.

H3c. Lighting positively affects the confirmation of visiting customers' expectations regarding ambiance quality.

H3d. Design and décor positively affects the confirmation of visiting customers' expectations regarding ambiance quality.

\section{Methodology}

\subsection{Data Collection}

The data collection comprised three steps. First, we shot three green restaurant videos related to the information customers need when they select restaurants. Ten marketing graduates were recruited to rate the three videos based on their technical and content quality. The video that received the highest score was used as the research background material. It was one minute in length, including a frame about the menu, ready food, employees, employees serving food, interior design and décor, lighting, environment, and so on.

Second, we recruited 12 marketing graduates to participate in the pre-test. The participants watched the video and were asked to fill out a questionnaire. We modified the questionnaire based on their feedback.

Third, 280 undergraduates in China were invited to participate in the investigation from 25-31 January, 2018. This step included three stages. First, the participants were asked to imagine that they had received a recommendation from a nearby green restaurant by mobile phone at lunch time when they were shopping at a shopping center. They had never consumed in the green restaurant. As the recommendation information was attractive, they decided to make an on-the-spot investigation of the restaurant before making a decision. Second, the participants watched the green restaurant video. Afterward, they were asked to fill in the questionnaire. Seven invalid questionnaires were excluded due to incomplete answers. The sample comprised 261 valid questionnaires. The participants consisted of $47 \%$ males and $53 \%$ females.

\subsection{Measurement}

Food presentation refers to the visually attractiveness of food. Freshness refers to the extent of freshness of the food. Variety refers to the availability of green food choices. Measures for presentation, freshness and variety were adapted from Oyewole [32] and Namkung and Jang [15]. 
Employees refers to the attitude of employees. Service refers to the speed of service of employees. Measures for employees and service were adapted from Liu and Jang [16].

Cleanliness pertains to the tidiness of the green restaurant. Appearance refers to the neatness and appropriateness of the staff's appearance. Lighting pertains to the appropriateness of the lighting. Design and décor pertains to the appropriateness of the design and décor. Measures for appearance were adapted from Andaleeb and Conway [33] and Liu and Jang [16]. Measures for cleanliness were adapted from Siu et al. [34]. Measures for lighting and design and décor were adapted from Chen et al. [13], Kwok et al. [14], and Andaleeb and Conway [33].

Expectation confirmation of food quality refers to the extent to which visiting consumers' food quality expectations were confirmed. Expectation confirmation of service quality refers to the extent to which visiting consumers' service quality expectations were confirmed. Expectation confirmation of ambiance quality refers to the extent to which visiting consumers' ambiance quality expectations were confirmed. Measures for these variables were adapted from Chang and Zhu [20] and Bhattacherjee [24].

Patronage intention refers to the possibility that visiting customers will decide to eat in the green restaurant involved in a location-based recommendation. Measures for patronage intention were adapted from Zhu and Chang [35].

The measurement items for each variable are shown in Table 3. Among them, the items of variety, lighting, and design and décor include the green features of the green restaurant. All scale items were measured using a five-point Likert scale anchored between "strongly disagree (1)" and "strongly agree (5)."

Table 3. Latent variable statistics.

\begin{tabular}{|c|c|c|c|c|c|}
\hline Variable & Item & Loading & AVE & CR & $\alpha$ \\
\hline \multirow{3}{*}{$\begin{array}{l}\text { Presentation } \\
\qquad(P R)\end{array}$} & Food looks tasty. & 0.840 & \multirow{3}{*}{0.776} & \multirow{3}{*}{0.912} & \multirow{3}{*}{0.855} \\
\hline & Food looks delicious. & 0.909 & & & \\
\hline & Food presentation is visually attractive. & 0.892 & & & \\
\hline \multirow{2}{*}{$\begin{array}{l}\text { Freshness } \\
\quad(\text { FR) }\end{array}$} & Food looks fresh. & 0.929 & \multirow{2}{*}{0.815} & \multirow{2}{*}{0.898} & \multirow{2}{*}{0.773} \\
\hline & The restaurant offers fresh food. & 0.936 & & & \\
\hline \multirow{2}{*}{$\begin{array}{l}\text { Variety } \\
\text { (VA) }\end{array}$} & The restaurant offers wide variety of green food. & 0.904 & \multirow{2}{*}{0.869} & \multirow{2}{*}{0.930} & \multirow{2}{*}{0.869} \\
\hline & The restaurant offers a lot of choices of green food. & 0.901 & & & \\
\hline \multirow{3}{*}{$\begin{array}{l}\text { Expectation } \\
\text { confirmation } \\
\text { of food } \\
\text { quality } \\
\text { (ECFQ) }\end{array}$} & $\begin{array}{l}\text { The food provided by the green restaurant is better than } \\
\text { what I expected. }\end{array}$ & 0.800 & \multirow{3}{*}{0.714} & \multirow{3}{*}{0.882} & \multirow{3}{*}{0.799} \\
\hline & $\begin{array}{l}\text { The food quality of the green restaurant is better than } \\
\text { what I expected. }\end{array}$ & 0.882 & & & \\
\hline & Overall, most of my food expectations are confirmed. & 0.850 & & & \\
\hline \multirow{2}{*}{$\begin{array}{l}\text { Employee } \\
\text { (EM) }\end{array}$} & The employees are friendly. & 0.911 & \multirow{2}{*}{0.835} & \multirow{2}{*}{0.910} & \multirow{2}{*}{0.802} \\
\hline & The employees are helpful. & 0.917 & & & \\
\hline \multirow{2}{*}{$\begin{array}{l}\text { Service } \\
\text { (SE) }\end{array}$} & The employees are attentive. & 0.713 & \multirow{2}{*}{0.751} & \multirow{2}{*}{0.854} & \multirow{2}{*}{0.790} \\
\hline & The restaurant offers prompt service. & 0.997 & & & \\
\hline \multirow{3}{*}{$\begin{array}{l}\text { Expectation } \\
\text { confirmation } \\
\text { of service } \\
\text { quality } \\
\text { (ECSQ) }\end{array}$} & $\begin{array}{l}\text { The service provided by the green restaurant is better than } \\
\text { what I expected. }\end{array}$ & 0.886 & \multirow{3}{*}{0.808} & \multirow{3}{*}{0.927} & \multirow{3}{*}{0.881} \\
\hline & $\begin{array}{l}\text { The service quality of the green restaurant is better than } \\
\text { what I expected. }\end{array}$ & 0.906 & & & \\
\hline & Overall, most of my service expectations are confirmed. & 0.905 & & & \\
\hline \multirow{2}{*}{$\begin{array}{l}\text { Appearance } \\
\text { (AP) }\end{array}$} & The employees dress appropriately. & 0.864 & \multirow{2}{*}{0.719} & \multirow{2}{*}{0.837} & \multirow{2}{*}{0.610} \\
\hline & The employees have neat appearance. & 0.831 & & & \\
\hline \multirow{3}{*}{$\begin{array}{l}\text { Design and } \\
\text { décor } \\
\text { (DD) }\end{array}$} & A lot of green plants are planted in the restaurant. & 0.829 & \multirow{3}{*}{0.735} & \multirow{3}{*}{0.892} & \\
\hline & Decorative materials are green. & 0.866 & & & 0.822 \\
\hline & The design and décor are appealing. & 0.876 & & & \\
\hline
\end{tabular}


Table 3. Cont.

\begin{tabular}{|c|c|c|c|c|c|}
\hline Variable & Item & Loading & AVE & CR & $\alpha$ \\
\hline \multirow{2}{*}{$\begin{array}{l}\text { Lighting } \\
\text { (LI) }\end{array}$} & The lighting is appropriate. & 0.890 & \multirow{2}{*}{0.820} & \multirow{2}{*}{0.901} & \multirow{2}{*}{0.782} \\
\hline & The lights are natural. & 0.921 & & & \\
\hline \multirow{2}{*}{$\begin{array}{l}\text { Cleanliness } \\
\text { (CL) }\end{array}$} & The facility is clean. & 0.898 & \multirow{2}{*}{0.845} & \multirow{2}{*}{0.916} & \multirow[b]{2}{*}{0.819} \\
\hline & The restaurant is a clean environment. & 0.939 & & & \\
\hline \multirow{3}{*}{$\begin{array}{c}\text { Expectation } \\
\text { confirmation } \\
\text { of ambiance } \\
\text { quality } \\
\text { (ECAQ) }\end{array}$} & $\begin{array}{l}\text { The ambiance provided by the green restaurant is better } \\
\text { than what I expected. }\end{array}$ & 0.882 & \multirow{3}{*}{0.748} & \multirow{3}{*}{0.899} & \multirow{3}{*}{0.832} \\
\hline & $\begin{array}{l}\text { The ambiance quality of the green restaurant is better than } \\
\text { what I expected. }\end{array}$ & 0.863 & & & \\
\hline & Overall, most of my ambiance expectations are confirmed. & 0.850 & & & \\
\hline \multirow{3}{*}{$\begin{array}{l}\text { Patronage } \\
\text { intention } \\
(\mathrm{PI})\end{array}$} & The likelihood of eating in the green restaurant is high. & 0.913 & \multirow{3}{*}{0.819} & \multirow{3}{*}{0.931} & \multirow{3}{*}{0.889} \\
\hline & $\begin{array}{l}\text { The probability that I would consider eating in the green } \\
\text { restaurant is high. }\end{array}$ & 0.900 & & & \\
\hline & My willingness to eat in the green restaurant is high. & 0.902 & & & \\
\hline
\end{tabular}

\subsection{Common Method Bias}

Harman's single-factor test has been widely used in assessing common method bias. The results of an exploratory factor analysis entering all measurement items show that the largest variance explained by an individual factor is $37 \%$. Common method variance may be a problem when the variables all load on one factor or one factor explains the majority of the variance [36]. Hence, common method bias was not a significant problem for this study.

\section{Result}

The present study adopted the statistics software Smart PLS 2.0 M3 to test the research model [37]. When using PLS, the recommended minimum sample size is ten times the number of items for the most complex variable [38]. Hence, the sample size of the current study met the requirement.

\subsection{Measurement Model}

In terms of reliability analysis, the Cronbach $\alpha$ value of all variables was above 0.6 , meeting the evaluation criterion of Nunnally [39]. In addition, the composite reliability (CR) value of all factors was above 0.8 (Table 3), meeting the criterion of strong reliability [40]. This demonstrates that the measurement model has good reliability.

In terms of validity analysis, the factor loading of all items was higher than 0.7 , and the average variance extracted (AVE) value of all constructs was higher that 0.7 (Table 3), which supports the convergent validity of the measurement model [41]. In addition, the squared root of the AVE values of all constructs were higher than the corresponding correlations among the latent constructs (Table 4), which supports the discriminant validity of the measurement model [41]. These demonstrated that the measurement model had good constructive validity. 
Table 4. Correlation of constructs and AVE.

\begin{tabular}{|c|c|c|c|c|c|c|c|c|c|c|c|c|c|}
\hline & PR & FR & VA & EM & SE & DD & LI & CL & AP & ECFQ & ECSQ & ECAQ & INT \\
\hline PR & 0.881 & & & & & & & & & & & & \\
\hline FR & 0.559 & 0.903 & & & & & & & & & & & \\
\hline VA & 0.434 & 0.444 & 0.932 & & & & & & & & & & \\
\hline EM & 0.435 & 0.416 & 0.188 & 0.914 & & & & & & & & & \\
\hline SE & 0.134 & 0.040 & 0.141 & 0.064 & 0.867 & & & & & & & & \\
\hline DD & 0.525 & 0.468 & 0.264 & 0.476 & 0.077 & 0.857 & & & & & & & \\
\hline LI & 0.312 & 0.421 & 0.223 & 0.458 & 0.004 & 0.563 & 0.906 & & & & & & \\
\hline CL & 0.470 & 0.567 & 0.391 & 0.440 & 0.088 & 0.537 & 0.458 & 0.919 & & & & & \\
\hline $\mathrm{AP}$ & 0.552 & 0.564 & 0.335 & 0.598 & -0.016 & 0.640 & 0.582 & 0.694 & 0.848 & & & & \\
\hline ECFQ & 0.566 & 0.607 & 0.432 & 0.420 & 0.046 & 0.387 & 0.387 & 0.436 & 0.448 & 0.845 & & & \\
\hline ECSQ & 0.423 & 0.448 & 0.153 & 0.671 & 0.079 & 0.518 & 0.364 & 0.452 & 0.523 & 0.449 & 0.899 & & \\
\hline ECAQ & 0.438 & 0.546 & 0.232 & 0.589 & 0.009 & 0.579 & 0.458 & 0.620 & 0.591 & 0.454 & 0.572 & 0.865 & \\
\hline INT & 0.571 & 0.569 & 0.340 & 0.543 & 0.066 & 0.634 & 0.431 & 0.584 & 0.640 & 0.515 & 0.663 & 0.648 & 0.905 \\
\hline
\end{tabular}

\subsection{Structural Model}

The results of the structural model test show that the standardization path coefficients were statistically significant $(p<0.05)$, except for the path coefficients of service for the expectation confirmation of service quality, and appearance and lighting for the expectation confirmation of ambiance quality. The $\mathrm{R}^{2}$ of the expectation confirmation of food quality, service quality, ambiance quality, and patronage intention were $0.457,0.452,0.484$, and 0.573 , respectively (Figure 2).

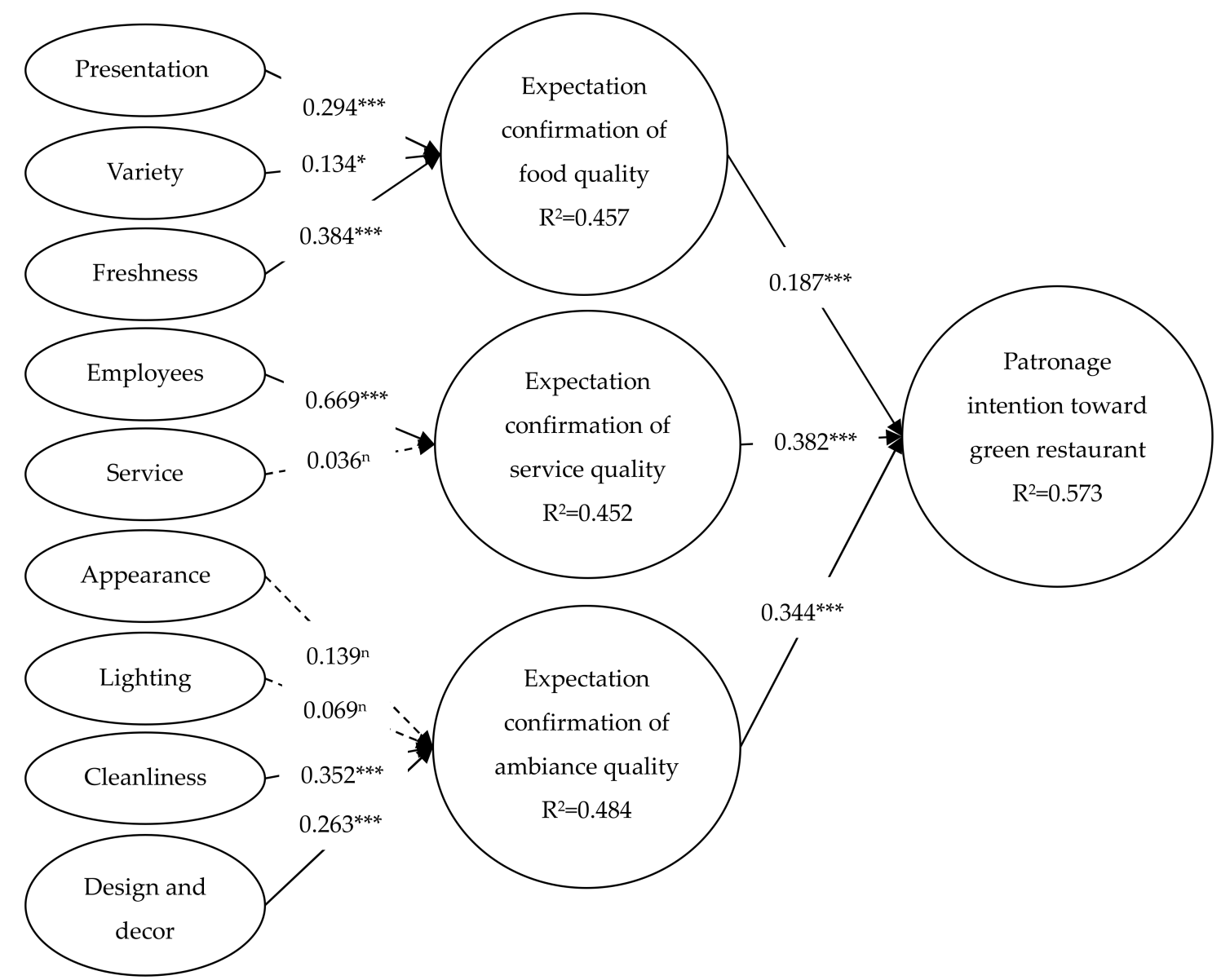

Figure 2. The PLS model. Note: ${ }^{* * *}=p<0.001,{ }^{*}=p<0.05, \mathrm{n}=$ not significant. 
Figure 2 indicates that expectation confirmation of food quality $(\beta=0.187, p<0.001)$, service quality $(\beta=0.382, p<0.001)$, and ambiance quality $(\beta=0.344, p<0.001)$ had a positive effect on patronage intention. As we hypothesized that expectation confirmation of food quality, service quality and ambiance quality would positively affect patronage intention, hypotheses $\mathrm{H} 1, \mathrm{H} 2$ and H3 were supported. Food presentation $(\beta=0.294, p<0.001)$, variety $(\beta=0.134, p<0.05)$, and freshness $(\beta=0.384, p<0.001)$ positively affected the expectation confirmation of food quality. As we hypothesized that food presentation, variety, and freshness would positively affect the expectation confirmation of food quality, hypotheses $\mathrm{H} 1 \mathrm{a}, \mathrm{H} 1 \mathrm{~b}$, and $\mathrm{H} 1 \mathrm{c}$ were supported. Employee ( $\beta=0.669, p<0.001)$ significantly impacted the expectation confirmation of service quality. The effect of service $(\beta=-0.036, p>0.05)$ on the expectation confirmation of service quality was not significant. As we hypothesized that employee and service would affect the expectation confirmation of service quality, H2a was supported, but $\mathrm{H} 2 \mathrm{~b}$ was not supported. Cleanliness $(\beta=0.352, p<0.001)$ and design and décor $(\beta=0.263, p<0.001)$ positively affected the expectation confirmation of ambiance quality. As we hypothesized that appearance, cleanliness, lighting, and design and décor would positively affect the expectation confirmation of ambiance quality, hypotheses H3b and H3d were supported, while $\mathrm{H} 3 \mathrm{a}$ and $\mathrm{H} 3 \mathrm{c}$ were not.

\section{Discussion}

Confirmation of visiting consumers' expectations of food quality, service quality and ambiance quality positively affect their patronage intentions regarding green restaurants in the context of location-based recommendations. On the one hand, the results of the present study are consistent with the conclusions of previous studies that investigated the effect of product quality, service quality and ambiance quality on patronage intentions in other situations [29,31]. Hence, product, service and ambiance quality are important antecedents of patronage intentions regardless of whether the establishment is a green restaurant, retail store or clothing store. On the other hand, though previous studies generally argued that that food quality is the most important antecedent of restaurant patronage [16], the path coefficients of this study show that service and ambiance quality have a greater impact on visiting consumers' patronage intentions regarding green restaurants. Given that environment-focused attributes are the most important green attributes of a restaurant $[7,9,14]$ and that people with higher education are more conscious regarding green practices [11], these may be the reasons that green design and décor, environmental cleanliness, and friendly and helpful employees are more important than food quality in the context of green restaurants.

With regard to food-related attributes, food presentation, variety and freshness positively affect the expectation confirmation of food quality. This finding is consistent with that of the other scholars [14,29-31]. When customers choose a green restaurant, they care about food quality. Customers' requirements for green foods include attractive food, various menu items of green food and fresh materials.

With regard to service-related attributes, the attitude of employees significantly influences the expectation confirmation of service quality. When customers enter a green restaurant and see staff with a friendly attitude, the perception will improve their evaluation of the service quality of the restaurant. This finding is consistent with other findings $[16,33]$. Such an evaluation increases the positive confirmation of service expectation for the restaurant. Despite this influence, prompt service does not have a significant relationship with service quality. As green restaurants generally have a good green environment, consumers may like to spend more time in green restaurants to enjoy the food and ambiance. Kwok et al. found that younger consumers are likely to wait for a long time at a green restaurant [14]. As consumers are likely to spend more time in green restaurants, their expectations of the speed of service may not be high. This may be the reason that the present study did not find that service affects visiting customers' expectations of service quality.

With regard to ambiance-related attributes, cleanliness and design and décor positively affected the expectation confirmation of ambiance quality. This finding is consistent with previous studies 
that focused on the effect of ambiance on customer satisfaction and patronage intentions [34,42]. Environmental cleanliness and green design and décor in a green restaurant create a green atmosphere for customers, resulting in a sense of enjoyment. This feeling of comfort and environmental protection promotes customers' perception of the ambiance quality. Despite this influence, employee appearance and lighting did not have a significant relationship with service quality. As environmental concerns are important antecedents of the patronage intentions of green restaurant consumers [7], visiting consumers may not pay much attention to the appearance of employees in the context of green restaurants. In addition, as a video of a green restaurant was used as the research background material of this study, the respondents' perception of the lighting may be not have been precise; this needs to be further investigated in the future.

\section{Implications and Limitations}

\subsection{Implications}

\subsubsection{Theoretical Implications}

First, the present study investigated the influence of restaurant quality on the intentions of visiting consumers to patronize a green restaurant. Previous studies have mainly investigated the antecedents of patronage intentions toward green restaurants from the aspect of consumer knowledge and beliefs regarding green consumption and individual characteristics [7-12], and consumer responses to the green attributes and green supply chain practices of green restaurants and other green consumption cues $[13,14,43,44]$. The present study is the first to investigate the antecedents of visiting customers' green restaurant patronage intentions from the perspective of restaurant quality, which provides additional insights into the antecedents of green consumption.

Second, the present study conducted a systematic study of how the food, service, and ambiance-related attributes of green restaurants influence the confirmation of visiting customers' expectations of restaurant quality and subsequent patronage intentions in the context of location-based recommendations. Bujisic et al. have argued that the type of restaurant moderates the relationship between restaurant quality and consumer behavioral intentions [6,45]. The present study is the first to systematically investigate the food-, service- and ambiance-related attributes of green restaurants that have an influence on the confirmation of visiting customers' expectations of restaurant quality and patronage intentions in the context of location-based recommendations. In addition, though previous studies have generally argued that food quality is the most important antecedent of restaurant patronage [16], this study shows that service and ambiance quality have a greater impact on the green restaurant patronage intention of visiting consumers. Moreover, though previous studies have generally argued that prompt service is an important attribute of restaurant service quality [16,33], this study shows that prompt service has no significant impact on the confirmation of visiting customers' expectations of the service quality of green restaurants.

Third, the study systematically investigated the influence of food, service and ambiance quality on visiting consumers' intentions to patronize a green restaurant based on the expectation confirmation theory. Although several studies focused on repeat patronage have comprehensively considered the food, service and ambiance quality $[4,5,18]$, the existing literature on initial patronage lacks systematic research into these elements. The present study focused on visiting consumers' green restaurant patronage intentions, providing additional insights into the influence of restaurant quality on customer decisions. In addition, the present study extended the application of expectation confirmation theory to understand the decision process of visiting consumers in the context of mobile advertisements.

\subsubsection{Practical Implications}

Green restaurants should pay attention to improving the confirmation of visiting customers' expectations regarding food, service and ambiance to increase their patronage intentions. In particular, 
green restaurants should provide good presentation, a selection of various green foods, and fresh materials to improve the confirmation of visiting customers' expectations regarding food quality, thereby promoting their patronage intentions. In addition, green restaurants should provide friendly service through employee training. Such efforts will increase the confirmation of visiting consumers' expectations regarding service quality and patronage intention. Green restaurants can also improve the green design of their establishments and maintain restaurant cleanliness in order to increase the confirmation of visiting consumers' expectations regarding ambiance quality, thereby promoting patronage intention. If green restaurants can improve the attributes of food, service and ambiance, they will then increase visiting customers' patronage intentions.

\subsection{Limitations and Further Study}

This study provides meaningful conclusions, but further investigations should be conducted. First, the study focuses on green restaurants and does not investigate other kinds of restaurants. Thus, the applicability of the conclusions to other types of restaurant is not clear. Future research must study other types of restaurant. Second, the research participants were undergraduates who share a similar age and educational background, thereby resulting in a narrow sample. The conformity of the findings with other consumer groups is not clear. Third, the study collected data in China. The difference in patronage intentions between green restaurants in China and those in other countries was not examined. Future studies can conduct such a comparison. Fourth, this study employed a video of a green restaurant as the research background material for the study, which may have influenced the respondents' perception of the lighting. Future studies can conduct the survey with a field investigation.

Acknowledgments: This work was supported by the National Natural Science Foundation of China (71302093) and the Fundamental Research Funds for the Central Universities (30918013122).

Author Contributions: Min Luo, Yi Shan Yu and Dong Hong Zhu originated the study. Min Luo led the writing of the article. Yi Shan Yu collected data and conducted the empirical analysis. Dong Hong Zhu contributed to the writing of the article.

Conflicts of Interest: The authors declare no conflict of interest.

\section{References}

1. Wu, C.H.; Kao, S.C.; Wu, C.C.; Huang, S. Location-aware service applied to mobile short message advertising: Design, development, and evaluation. Inf. Process. Manag. 2015, 51, 625-642. [CrossRef]

2. Zhu, D.H.; Chang, Y.P.; Luo, J.J.; Li, X. Understanding the adoption of location-based recommendation agents among active users of social networking sites. Inf. Process. Manag. 2014, 50, 675-682. [CrossRef]

3. Zhu, D.H.; Sun, H.; Chang, Y.P. How the content of location-based advertisings influences consumers' store patronage intention. J. Consum. Mark. 2017, 34, 603-611. [CrossRef]

4. Line, N.D.; Hanks, L.; Kim, W.G. Hedonic adaptation and satiation: Understanding switching behavior in the restaurant industry. Int. J. Hosp. Manag. 2016, 52, 143-153. [CrossRef]

5. Ha, J.; Jang, S.C. Attributes, consequences, and consumer values A means-end chain approach across restaurant segments. Int. J. Contemp. Hosp. Manag. 2013, 25, 383-409. [CrossRef]

6. Bujisic, M.; Hutchinson, J.; Parsa, H.G. The effects of restaurant quality attributes on customer behavioral intentions. Int. J. Contemp. Hosp. Manag. 2014, 26, 1270-1291. [CrossRef]

7. Hu, H.H.; Parsa, H.G.; Self, J. The Dynamics of Green Restaurant Patronage. Cornell Hosp. Q. 2010, 51, 344-362. [CrossRef]

8. Liu, M.; Yu, Y.F. The Impact of Consumers' Beliefs on Attitudes and Patronage Intention toward Green Restaurant in Taiwan. Adv. Mater. Res. 2012, 524-527, 3501-3504. [CrossRef]

9. Teng, Y.-M.; Wu, K.-S.; Huang, D.-M. The Influence of Green Restaurant Decision Formation Using the VAB Model: The Effect of Environmental Concerns upon Intent to Visit. Sustainability 2014, 6, 8736-8755. [CrossRef] 
10. Chou, C.-J.; Chen, K.-S.; Wang, Y.-Y. Green practices in the restaurant industry from an innovation adoption perspective: Evidence from Taiwan. Int. J. Hosp. Manag. 2012, 31, 703-711. [CrossRef]

11. DiPietro, R.B.; Yang, C.; Charles, P. Green practices in upscale foodservice operations: Customer perceptions and purchase intentions. Int. J. Contemp. Hosp. Manag. 2013, 25, 779-796. [CrossRef]

12. Namkung, Y.; Jang, S. Are Consumers Willing to Pay more for Green Practices at Restaurants? J. Hosp. Tour. Res. 2017, 41, 329-356. [CrossRef]

13. Chen, C.-T.; Cheng, C.-C.; Hsu, F.-S. GRSERV scale: An effective tool for measuring consumer perceptions of service quality in green restaurants. Total Qual. Manag. Bus. Excell. 2015, 26, 355-367. [CrossRef]

14. Kwok, L.; Huang, Y.-K.; Hu, L. Green attributes of restaurants: What really matters to consumers? Int. J. Hosp. Manag. 2016, 55, 107-117. [CrossRef]

15. Namkung, Y.; Jang, S. Does food quality really matter in restaurant? Its impact on customer satisfaction and behavioral intentions. J. Hosp. Tour. Res. 2007, 31, 387-410. [CrossRef]

16. Liu, Y.; Jang, S. Perceptions of Chinese restaurants in the US: What affects customer satisfaction and behavioral intentions? Int. J. Hosp. Manag. 2009, 28, 338-348. [CrossRef]

17. Zhu, D.H.; Chang, Y.P.; Chang, A. Effects of free gifts with purchase on online purchase satisfaction: The moderating role of uncertainty. Internet Res. 2015, 25, 690-706. [CrossRef]

18. Barber, N.; Goodman, R.J.; Goh, B.K. Restaurant consumers repeat patronage: A service quality concern. Int. J. Hosp. Manag. 2011, 30, 329-336. [CrossRef]

19. Baker, J.; Parasuraman, A.; Grewal, D.; Voss, G.B. The Influence of Multiple Store Environment Cues on Perceived Merchandise Value and Patronage Intentions. J. Mark. 2002, 66, 120-141. [CrossRef]

20. Chang, Y.P.; Zhu, D.H. The role of perceived social capital and flow experience in building users' continuance intention to social networking sites in China. Comput. Hum. Behav. 2012, 28, 995-1001. [CrossRef]

21. Ayans, A.; Herath, T.C.; O'Brien, N. Understanding continuance intentions of physicians with electronic medical records (EMR): An expectancy-confirmation perspective. Decis. Support. Syst. 2015, 77, 112-122. [CrossRef]

22. Hu, M.Y.; Huang, F.; Hou, H.P.; Chen, Y.; Bulysheva, L. Customized logistics service and online shoppers' satisfaction: An empirical study. Internet Res. 2016, 26, 484-497. [CrossRef]

23. Oliver, R.L. A cognitive model of the antecedents and consequences of satisfaction decisions. J. Mark. Res. 1980, 17, 460-469. [CrossRef]

24. Bhattacherjee, A. Understanding information systems continuance: An expectation confirmation model. MIS Q. 2001, 25, 351-370. [CrossRef]

25. Song, S.M.; Kim, E.; Tang, R.; Bosselman, R. Exploring the determinants of e-commerce by integrating a technology-organization-environment framework and an expectation-confirmation model. Tour. Anal. 2015, 20, 689-696. [CrossRef]

26. Lan, Y.-L. Intentions to continue using a digital mammography vehicle based on the technology acceptance model and expectation confirmation theory. Asian Women 2017, 33, 23-40. [CrossRef]

27. Frank, B. The formation of consumer attitudes and intentions towards fast food restaurants: How do teenagers differ from adults? Manag. Serv. Qual. 2012, 22, 260-280. [CrossRef]

28. Swimberghe, K.R.; Wooldridge, B.R. Drivers of Customer Relationships in Quick-Service Restaurants: The Role of Corporate Social Responsibility. Cornell Hosp. Q. 2014, 55, 354-364. [CrossRef]

29. Pan, Y.; Zinkhan, G.M. Determinants of retail patronage: A meta-analytical perspective. J. Retail. 2006, 82, 229-243. [CrossRef]

30. Qin, H.; Prybutok, V.R. Determinants of customer-perceived service quality in fast-food restaurants and their relationship to customer satisfaction and behavior intentions. Qual. Manag. J. 2008, 15, 35-50. [CrossRef]

31. Rajic, T.; Dado, J. Modelling the relationships among retail atmospherics, service quality, satisfaction and customer behavioural intentions in an emerging economy context. Total Qual. Manag. Bus. Excell. 2013, 24, 1096-1110. [CrossRef]

32. Oyewole, P. The role of frequency of patronage and service quality of all-you-can-eat buffet restaurant: A perspective of socio-economic and demographic characteristics of African American consumers. Int. J. Hosp. Manag. 2013, 34, 202-213. [CrossRef]

33. Andaleeb, S.S.; Conway, C. Customer satisfaction in the restaurant industry: An examination of the transaction-specific model. J. Serv. Mark. 2006, 20, 3-11. [CrossRef] 
34. Siu, N.Y.M.; Wanb, P.Y.K.; Dongc, P. The impact of the servicescape on the desire to stay in convention and exhibition enters: The case of Macao. Int. J. Hosp. Manag. 2012, 31, 236-246. [CrossRef]

35. Zhu, D.H.; Chang, Y.P. Effects of interactions and product information on initial purchase intention in product placement in social games: The moderating role of product familiarity. J. Electron. Commer. Res. 2015, 16, 22-33.

36. Podsakoff, P.M.; Organ, D.W. Self-reports in organizational research: Problems and prospects. J. Manag. 1986, 12, 531-544. [CrossRef]

37. Ringle, C.M.; Wende, S.; Will, A. SmartPLS 2. SmartPLS. 2005. Available online: http:/ / www.smartpls.com (accessed on 2 February 2018).

38. Chin, W.W. The partial least squares approach for structural equation modeling. In Modern Methods for Business Research; Marcoulides, G.A., Ed.; Lawrence Erlbaum: Mahwah, NJ, USA, 1998; pp. 295-336.

39. Nunnally, J.C. Psychometric Theory; McGraw-Hill: New York, NY, USA, 1967.

40. Chin, W.W.; Gopal, A. Adoption intention in GSS: Relative importance of beliefs. Data Base Data Base Adv. Inf. Syst. 1995, 26, 42-64. [CrossRef]

41. Fornell, C.; Larcker, D.F. Structural equation models with unobservable variables and measurement errors. J. Mark. Res. 1981, 18, 39-50. [CrossRef]

42. Wakefield, K.L.; Blodgett, J.G. The effect of the servicescape on customers' behavioral intentions in leisure service settings. J. Serv. Mark. 1996, 10, 45-61. [CrossRef]

43. Chiu, J.-Z.; Hsieh, C.-C. The impact of restaurants' green supply chain practices on firm performance. Sustainability 2016, 8, 42. [CrossRef]

44. Gaker, D.; Walker, J.L. Revealing the value of "green" and the small group with a big heart in transportation mode choice. Sustainability 2013, 5, 2913-2927. [CrossRef]

45. DiPietro, R.B.; Parsa, H.G.; Gregory, A. Restaurant QSC inspections and financial performance: An empirical investigation. Int. J. Contemp. Hosp. Manag. 2011, 23, 982-999. [CrossRef]

(C) 2018 by the authors. Licensee MDPI, Basel, Switzerland. This article is an open access article distributed under the terms and conditions of the Creative Commons Attribution (CC BY) license (http:/ / creativecommons.org/licenses/by/4.0/). 